\title{
Bovine Viral Diarrhea-an Emerging Disease in Camelids a Review
}

\author{
Wernery, $\mathbf{U}$. \\ Central Veterinary Research Laboratory, P.O. Box 597, Dubai, UAE
}

Received 2012-06-28, Revised 2012-08-03; Accepted 2012-08-29

\begin{abstract}
Bovine Viral Diarrhea (BVD) is an emerging disease in both New World Camelids (NWCs) and Old World Camelids (OWCs). The virus has been isolated from NWCs particularly in alpacas and dromedaries, but there are no reports of BVD in Bactrians. BVD is an important infectious disease. Both sub-genotypes 1a, $1 \mathrm{~b}$ and genotype 2 have been isolated from NWCs but the ncp BVDV $1 \mathrm{~b}$ is primarily implicated in cases of BVD in NWCs. A BVD strain unique to camelids has not yet been isolated. In NWCs virtually all infections have been caused by the non-cytopathic (ncp) BVDV, Persistently infected crias have also been detected. Llamas and alpacas demonstrate clinical signs such as ill thrift, diarrhea, respiratory ailments and abortions. As in bovines, identification and elimination of PI animals, has the highest priority to avoid infection of the entire herd. BVD was also observed in dromedaries and interestingly, both genotypes of the Pestivirus, BVDV-1 and BVDV-2, were isolated from dromedaries in Egypt. Both isolates revealed a cytopathic effect (cpe) and so far no ncp virus has been isolated from dromedaries. Also in dromedaries, BVD infections caused intrauterine death, stillbirth, weak calf syndrome with congenital deformities, neonatal respiratory disorders in young dromedary calves and acute hemorrhagic gastroenteritis in adult dromedaries. So far, no PI dromedaries have been described.
\end{abstract}

Keywords: Bovine Viral Diarrhea Virus (BVDV), Mucosal Disease (MD), Old World Camels (OWCs), New World Camels (NWCs), Persistently Infected (PI)

\section{INTRODUCTION}

Bovine Viral Diarrhea Virus (BVDV) is responsible for two distinct clinical entities in cattle which are:

- Bovine Viral Diarrhea (BVD) resulting in high morbidity and low mortality

- Mucosal Disease (MD), which is sporadic but regularly fatal

Two genotypes of BVDV are recognized (BVDV-1, BVDV-2) and each genotype has 2 biotypes: noncytopathic (ncp) and cytopathic (cp). The nature of biotypes involved in BVDV infection play a pivotal role in the epidemiology and pathogenesis of the disease not only in cattle but also in camelids. Only ncp strains of BVDV produce Persistently Infected (PI) animals, whereas $\mathrm{cp}$ strains are derived by mutation from preexisting ncpBVDV strains and do not produce viremic animals. Only ncp strains are excreted and may infect other animals in a herd. These strains are also able to cross the placental barrier and infect the fetus in the early stages of gestation.
Bovine Viral Diarrhea (BVD) and Mucosal Disease (MD) are epidemiologically different diseases in cattle that have different pathogeneses, although both are caused by the same Pestivirus. Pestivirus infection can occur at any age in postnatal life and may be subclinical or produce a range of clinical conditions including acute diarrhea, acute hemorrhagic syndrome, acute fatal and wasting disease. The Pestivirus, widespread in cattle populations worldwide has also been isolated from New World Camels (NWCs) and Old World Camels (OWCs) (Evermann et al., 1993; Mattson, 1994; Hegazy et al., 1998).

Over many years a great amount of research has taken place mainly in NWCs in connection with the Pestivirus, which resulted in a number of publications as summarized in Table 1. It is now obvious that BVDV can produce cases of diarrhea, ill thrift, reproductive losses, respiratory disease and disseminated disease in NWCs (Kapil et al., 2009). A review article on BVDV infection in NWCs has been recently published by Amstel and Kennedy (2010). 
Table 1. Recent literature on BVD in OWCs and NWCs

\begin{tabular}{|c|c|c|c|c|}
\hline \multirow[b]{2}{*}{ Author } & \multicolumn{4}{|l|}{ NWCs } \\
\hline & Year & Country & Species & Result \\
\hline Rivera et al. & 1987 & Peru & Alpaca & serology $11 \%$ reactors \\
\hline Karesh et al. & 1998 & Argentina & Guanaco & serology all negative \\
\hline Belknap et al. & 2000 & USA & Llama & $\begin{array}{l}\text { virus isolated FAT negative immunoperoxidase } \\
\text { positive SNT negative }\end{array}$ \\
\hline Goyal et al. & 2002 & USA & Alpaca & ncp type $1 \mathrm{~b}$ isolated, $\mathrm{PCR}$ positive \\
\hline Wentz et al. & 2003 & USA & $\begin{array}{l}\text { Llama } \\
\text { Alpaca }\end{array}$ & $\begin{array}{l}\text { experimental infection no disease } \\
\text { seroprevalence is low } \\
\text { no fetal infection }\end{array}$ \\
\hline Carman et al. & 2005 & USA & Alpaca & $\begin{array}{l}\text { Systemic disease abortion, } \\
\text { virus isolation, persistent } \\
\text { infection, BVDV type } 1 \mathrm{~b}\end{array}$ \\
\hline Anonymous & 2005 & UK & Alpaca & $\begin{array}{l}\text { Systemic disease } \\
\text { abortion, ncp virus isolation, BVDV } \\
\text { type } 1 \mathrm{~b}\end{array}$ \\
\hline Anonymous & 2005 & UK & Alpaca & Ill thrift, diarrhea, type 1b BVDV \\
\hline Foster et al. & 2005 & UK & Alpaca & ncp BVDV type 1 \\
\hline \multirow[t]{2}{*}{ Evermann } & 2006 & USA & Llama & \\
\hline & & & Alpaca & $\begin{array}{l}\text { General article about BVD } \\
\text { in llama and alpaca }\end{array}$ \\
\hline Henningson et al. & 2006 & USA & Alpaca & $\begin{array}{l}\text { Persistently infected, } \\
\text { pathological lesions }\end{array}$ \\
\hline Bromage & 2006 & UK & Alpaca & General article \\
\hline Anonymous & $2006 a$ & UK & Alpaca & PCR positive for BVD type 1 , abortion \\
\hline Anonymous & $2006 b$ & UK & Alpaca & Abortion, weak crias, PCR, BVD type 1 positive \\
\hline Anonymous & $2006 b$ & USA & Camelids & General article \\
\hline Bedenice & 2006 & USA & NWCs & General article \\
\hline Evermann et al. & 2006 & USA & Camelids & General article \\
\hline Mattson et al. & 2006 & USA & Alpaca & Persistent infection, BVDV isolated \\
\hline Mueller and Broadbent & 2007 & $\begin{array}{l}\text { USA } \\
\text { UK }\end{array}$ & Camelids & General article \\
\hline Probst et al. & 2007 & European zoos & Camelids & Serology $1.4 \%$ \\
\hline Kelling & 2008 & USA & Alpaca & Serology $25.4 \%$ herds were positive \\
\hline Byers & 2008 & USA & Camelids & General article \\
\hline Bedenice & 2008 & USA & Alpaca & Persistent infection with BVDV type 1 \\
\hline \multirow[t]{2}{*}{ Danuser et al. } & 2009 & Switzerland & Alpaca & \\
\hline & & & Llama & Seroprevalence $4.6 \%$ \\
\hline Shimeld & 2009 & USA & alpaca & $\begin{array}{l}\text { Seroprevalence } 20 \% \text {, } \\
\text { persistently infected animals }\end{array}$ \\
\hline Kim et al. & 2009 & USA & alpaca & $\begin{array}{l}46 \mathrm{BVD} \text { viruses identified by } \\
\text { PCR, one genotype } 1 \mathrm{~b} \text { BVDV }\end{array}$ \\
\hline Topliff et al. & 2009 & USA & NWCs & $20 \%$ seroprevalence, $6 \%$ PI crias \\
\hline Mudry et al. & 2010 & Switzerland & NWCs & Serology $5.8 \%, 3.6 \%$, no pestiviral RNA found \\
\hline Johnson et al. & 2010 & USA & Alpacas & $\begin{array}{l}\text { Intranasal infection with BVDV } 1 \mathrm{~b} \text { and } 2 \text { from } \\
\text { bovine and BVDV } 1 \mathrm{~b} \text { from alpaca }\end{array}$ \\
\hline Byers et al. & 2010 & USA & Alpacas & Vaccination trial \\
\hline Byers et al. & 2011 & USA & Alpacas & Exposure of native alpacas from PI alpacas \\
\hline Bedenice et al. & 2011 & USA & Alpacas & 35 crias naturally infected with BVDV type $1 \mathrm{~b}$ \\
\hline Doyle and Heuschele & 1983 & USA zoos & Dromedary & Serology $13 \%$ \\
\hline Fahmy & $1999 a, 1999 b, 1999 c$ & Egypt & Dromedary & Experimental infections \\
\hline Yousif et al. & 2004 & Egypt & Dromedary & BVD virus type 1 and 2 isolated \\
\hline Al-Afaleq et al. & 2006 & Saudi Arabia & Dromedary & Seroprevalence $18 \%$ \\
\hline Taha & 2007 & UAE & Dromedary & Seroprevalence negative \\
\hline Wernery et al. & 2008 & UAE & Dromedary & Seroprevalence in camel dairy $1.6 \%$ \\
\hline
\end{tabular}




\subsection{Etiology}

Bovine Viral Diarrhea virus (BVDV) is a small RNA virus of the Flaviviridae. Together, with the viruses of border disease and classical swine fever virus, it forms the genus Pestivirus.

The three viruses are antigenically related. Strains isolated from newborn calves and persistently infected cattle, are generally non-cytopathic (ncpBVDV), while those from tissues of cattle suffering from MD are usually cytopathic (cpBVDV). Today two genotypes of BVDV are recognized: BVDV-1 and BVDV-2 based on the nucleotide sequence of the 5'- untranslated region. BVDV-1 has a worldwide distribution, whereas BVDV2 is largely restricted to the USA and Canada but has also been isolated in Italy, Holland and the UK (Reed, 2010). Each of the two genotypes has two biotypes, noncytopathic (ncp) and cytopathic (cp) (Peterhans et al., 2010). Genotype 1 isolates are further divided into at least 2 sub-genotyes (1a and 1b). Particularly in alpacas both sub-genotypes $1 \mathrm{a}, 1 \mathrm{~b}$ and genotype 2 have been isolated (Amstel and Kennedy, 2010). Non cytopathic BVDV $1 b$ is primarily found in NWCs. A BVDV strain unique to camelids has not yet been identified.

\subsection{Epidemiology}

Postnatal infection with the virus is acquired by ingestion or inhalation of contaminated material which results in the development of serum neutralizing antibodies. This is usually a clinically unrecognizable infection. On the other hand, with infection of a nonimmune pregnant animal, the virus always crosses the placental barrier and invades the fetus. While the dam seroconverts without showing signs of disease, the fetus is immunotolerant in the early stages of pregnancy. This congenital infection can result in a wide spectrum of abnormalities; fetal death, congenital defects, or a persistent lifelong infection without clinical signs. The outcome is mainly dependent on the stage of fetal development during which time the infection takes place. BVDV is also transmitted in semen, particularly from persistently infected bulls, which shed the virus in their semen for their whole life.

Many years were required before understanding the complexity of infection with the Pestivirus, especially the link between BVD and MD in cattle. Pestivirus infection has only been recently recognized as a potential cause of serious illness in both NWCs and OWCs (Evermann, 2006), indicating that members of the camelid group are susceptible to infection. In NWCs, Pestivirus has been intensively researched in North
America (Byers, 2008; Kim et al., 2009), the UK (Mueller and Broadbent, 2007) as well as in Switzerland (Danuser et al., 2009). BVDV may cause a severe disease in alpacas and llamas, including diarrhea, reproductive loss, wastage and death, posing a significant threat to a herd's health as it does in bovines (Belknap et al., 2000). The emerging BVDV infections have raised significant concerns in the camelid industries in North America and Europe, especially in the UK, Switzerland and Germany that have strong NWC societies. Similar to cattle, there is not only a systemic disease caused by the Pestivirus but also persistent BVDV infection in NWCs may occur, when the fetus is infected during early pregnancy, before it becomes immunocompetent. Field observations have shown that up to $80 \%$ of crias born to naïve dams infected during early pregnancy may become Persistently Infected (PI) with the Pestivirus (Bedenice, 2008; Bedenice et al., 2011). At a population level in bovines, the prevalence of PI animals is about $1 \%$. So far, nearly all infections in SACs are caused by the ncpBVDV including the Persistently Infected (PI) crias. Only in one case was a cytopathic biotype documented from a llama foetus (Bedenice, 2006). However, serological investigations by Shimeld (2009) using serum virus neutralization (SN) with NADL (BVDV type 1) and c125 BVDV (BVDV type 2) on 426 alpaca sera, found that $20 \%$ of the alpaca, were sero-positive for one or both genotypes in the US.

PI animals are pivotal in the epidemiology of the disease (Byers et al., 2009) because they disseminate not only the ncpBVDV which they harbour, but also the $\mathrm{cp}$ BVDV derived by mutation. These PI animals must be eliminated from the herd as soon as possible. From 2004 to 2007 more than 12,000 alpacas in the US were screened by real-time PCR, to identify alpacas persistently infected with BVDV. A total of $46 \mathrm{BVDV}$ isolates were found and analyzed by comparison of nucleotide sequences of 2 viral genome regions. The results showed that unique genotypes of bovine BVDV $1 \mathrm{~b}$ are maintained in the alpaca population of the US. It is not yet clear why alpacas were predominantly infected with genotype $1 \mathrm{~b}$ BVDV isolates and how bovine BVDV evolved to infect alpacas, although camelids are susceptible to other genotypes (Kim et al., 2009). It is thought, that BVDV infection of camelids primarily originates from infected cattle via intermingling (Evermann, 2006).

The most likely route of BVDV infection in camelids is via the oronasal mucosa most probably after inhalation of viral particles which are present in body fluids of infected animals (Byers et al., 2011). 
In the US several other researchers have isolated the 1b BVDV (Carman et al., 2005) but the same genotype was also found in alpacas in the UK (Anonymous, 2005; Fahmy, 1999c) and Switzerland (Danuser et al, 2009). Mueller and Broadbent (2007) reported that the oldest surviving PI alpaca survived 30 months. In bovines, more than $50 \%$ of PI animals die before they reach the age of one year. PI bovines are mostly clinically healthy and excrete large quantities of BVDV, which is antigenically identical to the ncpBVDV present in the animal (Lefèvre et al., 2011). A similar pathogenesis can be expected to occur in NWCs but has not been described in OWCs. A report by Carman et al. (2005) indicates a BVDV infection, in utero, results in immunotolerant crias.

It is known that both llamas and alpacas are susceptible to BVDV infection and that in some cases, the animals demonstrate clinical signs such as diarrhea, ill thrift, respiratory ailment and abortion. BVD can be severely exacerbated in connection with a bovine tuberculosis (bTb) infection, leading to fatalities (Cobb and Cobb, 2010). It is also assumed that male camelids could, like bulls, persistently be infected.

Several researchers have also stressed that BVD is uncommon in SACs, despite the fact that $25 \%$ of the alpaca herds can be serologically positive (Kelling, 2008) with a seroprevalence of 20\% (Shimeld, 2009). The Alpaca Research Foundation of the US, believes that the incidence of clinical BVD in the US, is only $0.05 \%$ (Evermann et al., 2006; Shimeld, 2009). Topliff et al. (2009) reported in a recent nationwide survey of 63 herds, a prevalence of $25 \%$ seropositive crias, of which $6 \%$ had evidence of BVDV PI crias. Belknap et al. (2000) found a serological BVDV incidence in NWCs of $4.4 \%$ and Evermann (2006) as high as 53\%. In a comparative epidemiological study, conducted by Mudry et al. (2010) in Switzerland on llamas and alpacas in 2000 and 2008, it was found that Pestivirus infection is a negligible risk for the BVDV eradication programme. The seroprevalence and the pestiviral RNA seroprevalence was low, with $5.8 \%$ versus $0 \%$ in 2008 and $3.6 \%$ versus $0 \%$ in 2000. Byers et al. (2011) reported only mild sign in BVDV naive alpacas after they were exposed to two PI alpacas which shed BVDV type $1 b$ virus in most of their body fluids. Viremia was detected in the transient infected alpacas but viral shedding during the acute phase did not take place and antibodies appeared to be protective upon re-exposure to the type $1 \mathrm{~b}$ virus.

Two Pestivirus isolated by Hegazy et al. (1995) in Egypt, from adult dromedaries with diarrhoea and from dromedary calves born with congenital defects, were genotyped by Yousif et al. (2004). Genotyping revealed that isolate Giza4 and isolate Giza7 belong to BVDV-1 and BVDV-2, respectively.

\subsection{Clinical Signs and Pathology}

Serological studies indicate that NWCs and OWCs are susceptible to infection with the BVDV. The results of serological studies identifying BVDV antibodies in the dromedary have appeared, but no reports have been found from Bactrian camels. In dromedaries, seroprevalences between 2 and $50 \%$ have been reported. BVDV antibodies have appeared in dromedaries from Tunisia, with $3.9 \%$ positive cases (Burgemeister et al., 1975), from Oman, 6.7\% positive cases (Hedger et al., 1980), from Sudan, 15.5 and $15.7 \%$ positive cases (Bornstein and Musa, 1987; Bornstein et al., 1989) and from Somalia with $3.4 \%$ positive cases (Bornstein, 1988). Bohrmann et al. (1988) did not identify any antibodies to BVDV in Djibouti using the serum neutralization test. Wernery and Wernery (1990) explained the higher incidence of BVD in UAE breeding camels $(9.2 \%)$ when compared to racing dromedaries $(3.6 \%)$, with their larger breeding herds and closer contact with cattle herds. In a later survey (CVRL, 1998), these findings were confirmed using an antibody ELISA. The incidence of BVDV antibodies in 552 camels tested was, $0.5 \%$ in racing camels and $6.4 \%$ in breeding camels. The presence of neutralizing antibodies to BVDV was $11 \%$ in Egypt, with a peak of $23 \%$ in one area (Hegazy et al., 1993). In another Egyptian survey, Tantawi et al. (1994), detected 4.3\% BVDV positive dromedaries and Zaghana (1998) found that camels from Egypt, exhibited an even higher prevalence (52.5\%) of neutralizing antibodies to BVDV.

Doyle and Heuschele (1983) examined 24 sera with the SNT from dromedaries kept in American zoos, of which $13 \%$ had antibodies using the Singer BVDV strain. Newer seroepidemiological studies from Saudia Arabia and the United Arab Emirates showed a high seroprevalence with $18 \%$ (Al-Afaleq et al., 2006) in Saudia Arabia and a low seroprevalence in the UAE, with $1.6 \%$ in dairy dromedaries (Wernery et al., 2008) and no reactors in 812 sera by Taha (2007). As in OWCs, many BVD serological surveys have been conducted in NWCs, as can be seen from Table 1. In a serological survey conducted in Peru, involving 117 alpacas that grazed with cattle and sheep, the prevalence of antibodies to BVDV was $11 \%$ (Rivera et al., 1987) and Picton (1993) reported a prevalence of $4.4 \%$ in 270 llamas from Oregon in the USA. A study by Puntel et al. (1999) found $2.05 \%(8 / 390)$ reactors to the BVDV in 
llamas, from nine farms located in three different provinces in Argentina.

Cattle suffering from BVD and MD show lesions in the alimentary tract. The pathological changes in MD are much more severe than in BVD, the MD lesions are often found only in the upper alimentary tract. In both $\mathrm{BVD}$ and $\mathrm{MD}$, pathological changes consist mainly of erosions and ulcers of varying severity. These pathological lesions have not been described in NWCs, but PI alpacas revealed multifocal hepatic necrosis and bronchopneumonia, as well as severe thymicatrophy, as seen in bovine calves (Henningson et al., 2006). BVD viral antigen was widely distributed in the alpaca tissues mostly prominent in nerves, Tunica media and adventitia of vessels and macrophages in the gastrointestinal submucosa, urinary bladder submucosa, lungs and cerebrum, indicating a viremia. The authors concluded that PI alpacas thymicatrophy may indicate hosts defense deficits, similar to PI bovine calves.

Long-term clinicopathological characteristics of alpacas naturally infected with BVDV type $1 \mathrm{~b}$ were reported from Bedenice et al. (2011). Their investigation involved 35 crias which were naturally exposed to BVDV. Chronically infected and PI crias had developed a significantly lower birth weight, decreased growth rates, anemia and a monocytosis compared with control animals. BVDV type $1 \mathrm{~b}$ infection during early pregnancy resulted in a high incidence of PI crias which developed chronic wasting, diarrhea and severe respiratory distress.

Three groups of BVDV naïve alpacas containing six animals each where intra nasally infected with BVDV $1 \mathrm{~b}$ of bovine origin (group1), BVDV2 of bovine origin (group2) and BVDV 1b of alpaca origin (group3) to study clinical signs, viremia, seroconversion and hematological changes (Johnson et al., 2010). After infection all three genotypes induced nasal BVDV shedding, viremia and sero- conversion but there were differences in the median onset.

It is reported that alpacas develop a milder disease following BVDV infection compared to bovines which was investigated by Samson et al. (2011). The authors found that the limited permissiveness of alpaca cells to BVDV compared to bovine cells may be the reason for this phenomenon.

BVD infections have been described in dromedary calves from Egypt (Hegazy et al., 1998) causing intrauterine death, stillbirths and weak calf syndrome with congenital deformities, neonatal respiratory distress syndrome in young dromedary calves and acute hemorrhagic gastroenteritis in adult dromedaries. BVDV was isolated from lymphoid tissues, spleen, brain and kidney on Bovine Kidney Cells (BKC) causing a cytopathic (cpe) effect. The virus was also observed by immunofluorescence in different organs. The virus was then later genotyped by Yousif et al. (2004) and named Giza 4 and Giza 7, belonging to BVDV type 1 and BVDV type 2. No ncpBVDV was isolated and no reports exist that PI animals have been detected in dromedaries. Extensive studies have been carried out by Fahmy (1999a; 1999b; 19999c) on pregnant goats infected with the Egyptian isolates and a bovine BVD virus. These experimental trials included:

- Studies on the reproduction performance

- Studies on the effect of the fetus and newborn kids

- Clinicopathological studies

The inoculation of pregnant does at day 65 of gestation, with the bovine NADL BVDV, resulted in early abortions in $60 \%$ of inoculated does, whereas the cpe camel strain induced late abortions in $25 \%$. The aborted fetuses caused by both viruses were small in size, severely autolysed and had been obviously dead in uterus for a long period of time. The inoculated does revealed severe leukopenia and lymphopenia during the first 7 days p.i. with both strains. Lymphopenia lasted for 28days. The remaining does gave birth to healthy kids with weight comparable to control kids.

Hegazy et al. (1995) state that the main cause of abortion in dromedaries is caused by the BVDV, which can reach $50 \%$ in some herds. This statement is very controversial, as no abortions storm have been described in other countries.

In the UAE for example, adult dromedaries and calves that have died of other causes, are routinely virologically screened, including the fluorescence test for the presence of the BVDV. So far the results have always been negative (Wernery et al., 1992).

\subsection{Diagnosis}

Diagnosis of BVD and MD requires laboratory support in the form of virus isolation, virus antigen detection and serum antibody determination. Skin biopsies are the tissues of choice for the diagnosis of BVDV, using immunohistological techniques and are always positive in persistently infected animals (Braun et al., 1999). This method should also be applied in the diagnosis of this disease in camelids (Evermann et al., 1993).

Goyal et al. (2002) stressed multiple test systems should be applied for arriving a proper diagnosis because their immunhistochemical examination of 
various tissues were negative although a ncp type $1 \mathrm{~b}$ was isolated from the tissues.

Diagnosis of BVD in cattle must be carried out at two levels. Firstly, the serological status of the herd must be determined either by serum neutralization tests or by ELISAs. Competitive ELISAs have been developed and are ideal for serodiagnosis of camelids. If no reactor is found in a herd, the herd is considered free of BVD. On the other hand, if one or several animals are detected with BVDV antibodies, it is essential to search for PI animals. The presence of PI animals may gradually contaminate the entire herd and therefore, the identification and elimination has the highest priority. For the detection of PI animals, capture ELISAs and PCR assays are nowadays used. PCR assays can also differentiate between strains of type 1 and type 2 . Antibody ELISAs will not detect PI animals that are immunotolerant.

\subsection{Treatment and Prevention}

Knowledge and technical tools to control BVD are readily available and national control schemes in several European countries are now in place (Brownlie et al., 2000).

Economic losses caused by BVD/MD mainly arise from prenatal infections. It is therefore essential to remove all persistently infected animals and to vaccinate heifers prior to first breeding (Thiel et al., 1999). The main risk is the re-introduction of infection into a herd, through a serologically positive pregnant dam carrying an infected fetus, which will always give birth to infected animal. Since it is known that BVDV also causes abortions in camels, it may be necessary to adopt control and vaccination strategies similar to those carried out in cattle. Live and inactivated vaccines have been widely used in several countries. Live vaccines are not recommended in camelids, because a variety of adverse effects, have been observed using live BVDV vaccines in cattle. However, Byers et al. (2010) did not observe any adverse effects when nonpregnant female alpacas were vaccinated with a modified live BVDV vaccine and challenged 25 days post immunization by nasal and ocular inoculation with BVDV type $1 \mathrm{~b}$ strain. The modified-live BVDV type1 (Singer strain and BVDV type 2 (srain 125c) vaccine (Vista $3 \mathrm{SC}$ vaccine, Intervet/Shering Plough Animal Health, Millsboro, DE USA) was administered subcutaneously at a dose of $2 \mathrm{ml}$ according to the recommendation for use in cattle. Results of this vaccination experiment showed that the type $1 \mathrm{~b}$ BVDV challenge strain which originated from a persistently infected alpaca was not detected from the vaccinated alpacas but from the two unvaccinated controls.

However, inactivated vaccines are safer and can provide good protection. New developments have led to the production of vaccines from ncpBVDV strains. It has been shown that NWCs seroconverted after a regimen of three vaccinations using an inactivatedvirus preparation (Mattson, 1994).

\section{CONCLUSION}

Over the last years our knowledge of BVD in camelids has increased and it is obvious that both NWCs and OWCs can contract the disease. However, extensive studies are necessary to elucidate the entire disease pattern in this animal species, as with bovines, through extensive field observations and laboratory studies. Investigations in bovines, have led to a new understanding of the complex epidemiology and pathogenesis of BVD and MD and one can hope that this will also be the case for the camelid family.

\section{ACKNOWLEDGEMENT}

The researchers wish to thank Osk Lowe and the staff of the Central Veterinary Research Laboratory for their excellent technical support.

\section{REFERENCES}

Al-Afaleq, A., E.M.E. Abu-Elzein and A.A. Hegazy, 2006. Serosurveillance for antibodies against some viral diseases of livestock in camels (Camelus dromedarius) in Saudi Arabia. Proceedings of the International Scientific Conference on Camels, (ISCC' 06), Qassim University, Kingdom of Saudi Arabia, pp: 338-346.

Amstel, S.V. and M. Kennedy, 2010. Bovine viral diarrhea infections in new world camelids-A review. Small Ruminant Res., 91: 121-126. DOI: 10.1016/j.smallrumres.2010.03.018

Anonymous, 2005. Miscellaneous mammals. Vet. Record, 156: 728-728.

Anonymous, 2006a. Bovine viral diarrhea virus in camelids. Proceedings of the International Camelid Health Conference for Veterinarians, (ICHCV' 06), Ohio State University, USA., pp: 275-278.

Anonymous, 2006b. Miscellaneous mammals. Vet. Record, 159: 510-510. 
Bedenice, D., 2006. Bovine viral diarrhea virus (BVDV) in South American camelids. Proceedings of the International Camelid Health Conference for Veterinarians, (ICHCV' 06), Ohio State University, USA., pp: 256-262.

Bedenice, D., 2008. Immunological responses in BVDV persistently infected alpacas. Proceedings International Camelid Health Conference for Veterinarians, (ICHCV' 08), Ohio State University, USA., pp: 167-169.

Bedenice, D., E. Dubovi C.L. Kelling, J.N. Henningson and C.L. Topliff et al., 2011. Long-term clinicopathological characteristics of alpacas naturally infected with bovine viral diarrhea virus type Ib. J. Vet. Intern. Med., 25: 605-612. PMID: 21488962

Belknap, E.B., J.K. Collins, R.S. Larsen and K.P. Conrad, 2000. Bovine viral diarrhea virus in New World camelids. J. Vet. Diag. Invest., 12: 568-570. PMID: 11108460

Bohrmann, R., H.R. Frey and B. Liess, 1988. Survey on the prevalence of neutralizing antibodies to bovine viral diarrhea (BVD) virus, bovine herpes virus type 1 (BHV-1) and parainfluenza virus type 3 (PI-3) in ruminants in the Djibouti Republic. Dtsch. tierärztl. Wochenschr., 95: 99-102. PMID: 2838248

Bornstein, S. and B.E. Musa, 1987. Prevalence of antibodies to some viral pathogens, Brucella abortus and Toxoplasma gondii in Serum from Camels (Camelus dromedarius) in Sudan. J. Vet. Med. Series B, 34: 364-370. DOI: 10.1111/j.14390450.1987.tb00409.x

Bornstein, S., 1988. A disease survey of the Somali camel. SARE Report, Sweden.

Bornstein, S., B.E. Musa and F.M. Jama, 1989. Comparison of seroepidemiological findings of antibodies to some infectious pathogens of cattle in camels of Sudan and Somalia with reference to findings in other countries of Africa. Proceedings of the International Symposium of Development of Animal Resources in Sudan, (DARS' 89), Khartoum, pp: 28-34.

Braun, U., M. Schoenmann, F. Ehrensberger, M. Hilbe and M. Strasser, 1999. Intrauterine infection with bovine virus diarrhoea virus on alpine communal pastures in switzerland. J. Vet. Med. Series A, 46: 13-17. DOI: 10.1046/j.1439-0442.1999.00173.x

Bromage, G., 2006. BVDV in alpacas. Proccedings British Veterinary Camelid Society, (BVCS' 06), Alfriston, East Sussex and Atlantic Alpacas, UK., pp: 45-47.
Brownlie, J., I. Thompson and A. Curwen, 2000. Bovine virus diarrhoea virus-strategic decisions for diagnosis and control. Practice, 22: 176-187. DOI: 10.1136/inpract.22.4.176

Burgemeister, R., W. Leyk and R. Goessler, 1975. Untersuchungen über Vorkommen von Parasitosen, bakteriellen und viralen Infektionskrankheiten bei Dromedaren in Südtunesien. Dtsch. Tierärztl. Wschr., 82: 352-354.

Byers, S., 2008. Update on BVDB, BTV and WNV in camelids. Proceedings International Camelid Health Conference for Veterinarians, Ohio State University, USA., pp: 171-174.

Byers, S.R., J.F. Evermann, D.S. Bradway, A.L. Grimm and J.F. Ridpath et al., 2011. The effects of exposure of susceptible alpacas to alpacas persistently infected with bovine viral diarrhea virus. Can. Vet. J., 52: 263-271.

Byers, S.R., J.F. Evermann, D.S. Bradway, S.M. Parish and G.M. Barrington 2010. Evaluation of a commercial bovine viral diarrhea virus vaccine in nonpregnant female alpacas (Vicugna pacos).Vaccine, 28: 591-593. PMID: 19857453

Byers, S.R., K.R. Snekvik, D.J. Righter, J.F. Evermann and D.S. Bradway et al., 2009. Disseminated bovine viral diarrhea virus in a persistently infected alpaca (Vicugna Pacos) cria. J. Vet. Diagn. Invest., 21: 145-148. DOI: 10.1177/104063870902100125

Carman, S., N. Carr, J. DeLay, M. Baxi and D. Deregt et al., 2005. Bovine viral diarrhea virus in alpaca: Abortion and persistent infection. J. Vet. Diag. Invest., 17: 589-593. PMID: 16475521

Cobb, N. and G. Cobb, 2010. The bio-security imperative-One farm's struggle against a silent killer. Camelid Q.

CVRL, 1998. Annual report. Central Veterinary Research Laboratory, Dubai, UAE.

Danuser, R., H.R. Vogt, T. Kaufmann, E. Peterhans and R. Zanoni, 2009. Seroprevalence and characterization of pestivirus infections in small ruminants and new world camelids in Switzerland. Schweiz. Arch. Tierheilkd., 151: 109-117. DOI: 10.1024/0036-7281.151.3.109

Doyle, L.G. and W.P. Heuschele, 1983. Bovine viral diarrhea virus infection in captive exotic ruminants. JAVMA, 183: 1257-1259. PMID: 6315662

Evermann, J.F., 2006. Pestiviral infection of llamas and alpacas. Small Ruminant Res., 61: 201-206. 
Evermann, J.F., E.S. Berry, T.V. Baszler, T.L. Lewis and T.C. Byington et al., 1993. Diagnostic approaches for the detection of Bovine Viral Diarrhea (BVD) virus and related pestiviruses. J. Vet. Diagn. Invest., 5: 265-269. PMID: 8389602

Evermann, J.F., S. Byers, S.M. Parish, A. Tibary and D.S. Bradway et $a l$, , 2006. Bovine viral diarrhea virus in camelids: An emerging pathogen and ways to monitor herd infection. Proceedings of the International Camelid Health Conference for Veterinarians, Mar. 21-25, Columbus, Ohio. pp: 266-278.

Fahmy, L.S., 1999a. I-Studies on Pregnant Goats Experimentally Infected with Bovine Viral Diarrhea Virus Isolated from Camels. In: Studies on Camel Diseases in Egypt, Fahmy L.S., (Ed.)., Arab Center for the Studies of Arid Zones and Dry Lands, Damascus, pp: 7-27.

Fahmy, L.S., 1999b. II-Studies on the Effect on the Foeti and Newly Born Kids. In: Studies on Camel Diseases in Egypt, Fahmy L.S., (Ed.)., Arab Center for the Studies of Arid Zones and Dry Lands, Damascus, pp: 7-60.

Fahmy, L.S., 1999c. III-Clinicopathological studies on pregnant goats infected with bovine viral diarrhoea virus isolated from camels.

Foster, A.P., M. Houlihan, R.J. Higgins, J. Errington and G. Ibata et al., 2005. BVD virus in a British alpaca. Vet. Rec., 156: 718-719. PMID: 15923557

Goyal, S.M., M. Bonljihad, S. Hangerud and J. Ridpath, 2002. Isolation of bovine viral diarrhea virus from an alpaca. J. Vet. Diagn. Invert. 14: 523-525.

Hedger, R.S., T.R. Barnett and D.F. Gray, 1980. Some virus diseases of domestic animals in the Sultanate of Oman. Trop. Anim. Hlth. Prod., 12: 107-114. PMID: 6251586

Hegazy, A.A., A.A. El Sanousi, M.M. Lotfy and T.A. Aboellail, 1995. Pathological and virological studies on calf mortality: B- mortalities associated with bovine virus diarrhea virus infection. J. Egypt Med. Assoc. Proceedings of 22nd Arab Vet Medicen Congress, Mar. 19-23, Cairo, Egypt, pp: 493-503.

Hegazy, A.A., L.S. Fahmy, M.S. Saber, T.A. Aboellail and A.A. Yousif et al., 1998. Bovine virus diarrhea infection causes reproductive failure and neonatal mortality in the dromedary camel. Proceedings of the International Meeting on Camel Production and Future Perspectives. Al Ain, UAE, 2-3.
Hegazy, A.A., S.F. Lotfia and M.S. Saber, 1993. Prevalence of antibodies common in viral diseases of domestic animals among camels in Egypt.

Henningson, J.N., C.L. Topliff, D.J. Steffen, B.W. Brodersen and D.R. Smith et al., 2006. Viral antigen distribution in alpacas persistently infected with bovine viral diarrhea virus. Vet. Pathol., 43: 5-827.

Johnson, J.W., M.A. Edmorson, P.H. Wals, M.S.D. Marley and M.D. Givens, 2010. Comparison of clinical, hematological and virological findings in alpacas (Lama pacos) inoculated with bovine viral diarrhea virus isolates of alpaca or bovine origin. Small Ruminant Res., 94: 66-72.

Kapil, S., T. Yeary and J.F. Evermann, 2009. Viral diseases of new world camelids. Vet. Clin. Food Anim., 25: 323-337. PMID: 19460643

Karesh, B.W., M.M. Uhart, E.S. Dierenfeld, W.E. Braselton and A. Torres et al., 1998. Health evaluation of free-ranging guanaco (Lama guanicoe). J. Zoo Wildl. Med., 29: 134-141. PMID: 9732026

Kelling, C., 2008. Prevalence of BVDV infected US alpaca herds and factors associated with BVDV seropositive herd status. Proceedings International Camelid Health Conference for Veterinarians, (ICHCV’ 08), Ohio State University, USA., pp. 176181.

Kim, S.G. R.R. Anderson, J.Z. Yu, N.C. Zylich and H. Kinde et al., 2009. Genotyping and phylogenetic analysis of bovine viral diarrhea virus isolates from BVDV infected alpacas in North America. Vet. Microbiol., 136: 209-216. PMID: 19059738

Lefèvre P.C., J. Blancou, R. Chermette and G. Uilenberg, 2011. Infectious and Parasitic Diseases of Livestock. 1st Edn., Stylus Pub Llc, Paris, ISBN10: 2743008725, pp: 2000.

Mattson, D.E., 1994. Viral Diseases. Vet. Clin. North America: Food Ani. Practice, 10: 345-351.

Mattson, D.E., R.J. Baker, J.E. Catania, Sh. R. Imbur and K.K. Wellejns et al., 2006. Persistent infection with bovine viral diarrhea virus in an alpaca. J. Am. Vet. Med. Assoc., 228: 1762-1765. DOI: 10.2460/javma.228.11.1762

Mudry, M., M. Meylan, G. Regula, A. Steiner and R. Zanoni et al., 2010. Epidemiological study of pestiviruses in south american camelids in Switzerland. J. Vet. Intern. Med., 24: 1218-1223. DOI: 10.1111/j.1939-1676.2010.0577.x

Mueller, K. and R. Broadbent, 2007. General discussion on BVD and bluetongue. Proc. Br. Vet. Camelid Soc. 
Peterhans, E., C. Bachofen, H. Stalder and M. Schweizer, 2010. Cytopathic Bovine Viral Diarrhea Viruses (BVDV): Emerging pestiviruses doomed to extinction. Vet. Res., 41: 1-14. DOI: $10.1051 /$ vetres/2010016

Picton, R.A., 1993. Serologic survey of llamas in Oregon for antibodies to viral diseases of livestock. M.S. Thesis Oregon State University.

Probst, C., S. Speck and H. Hofer, 2007. Epidemiology of selected infectious diseases in zoo ungulates: single species versus mixed species exhibits. Verh.. Erkrg. Zootiere., 43: 10-12.

Puntel, M., N.A. Fondevila, J. Blanco Viera and V.K. O'Donnell et al., 1999. Serological survey of viral antibodies in llamas (Lama glama) in Argentina. J. Vet. Med. B., 46, 157-161. DOI: 10.1046/j.14390450.1999.00215.x

Reed, C., 2010. Import Risk analysis: Llamas (Lama glama) and alpacas (Vicugna pacos) from specified countries. Policy and Risk MAF Biosecurity, New Zealand.

Rivera, H., B.R. Madewell and E. Ameghino, 1987. Serologic survey of viral antibodies in the Peruvian alpaca (Lama pacos). Am. J. Vet. Res., 48: 189-191. PMID: 3826854

Samson, H.C., C.L. Topliff, R.O. Donis and C.L. Kelling, 2011. Comparison of viral replication and IFN response in alpaca and bovine cells following bovine viral diarrhea virus infection. Virology, 413: 111-117. DOI: 10.1016/j.virol.2011.02.006

Shimeld, L.A., 2009. Serological survey of alpacas living or breeding in Southern California. Proceedings of the 113th Annual Meeting of U.S.A Health Association, (HA' 09), San Diego.

Taha, T.H., 2007. Pathogens affecting the reproductive system of camels in the United Arab Emirates. M. Sc., Thesis, Swedish University of Agricultural Sciences, Uppsala.

Tantawi, H.W., R.R. Youssef, R.M. Arab, M.S. Marzouk and R.H. Itman, 1994. Some studies on bovine viral diarrhea disease in camel. Vet. Med. J., 32: 9-15.
Thiel, H.J., P. Becker, M. Baroth, M. Koenig and M. Orlich, 1999. Auftreten von MD nach Impfung.

Topliff, C.L., D.R. Smith, S.L. Clowser, D.J. Steffen and J.N. Henningson et al., 2009. Prevalence of bovine viral diarrhea virus infections in alpacas in the United States. J. Am. Vet. Med. Assoc., 234: 519-529. DOI: $10.2460 /$ javma.234.4.519

Wentz, P.A., E.B. Belknap K.V. Brock, J.K. Collins and D.G. Pugh, 2003. Evaluation of bovine viral diarrhea virus in New World camelids. J. Am. Vet. Med. Assoc., 223: 223-228. PMID: 12875452

Wernery, U. and R. Wernery, 1990. Seroepidemiologische Untersuchungen zum Nachweis von Antikörpern gegen Brucellen, Chlamydien, Leptospiren, BVD/MD, IBR/IPV-und Enzootischen Bovinen Leukosevirus (EBL) bei Dromedarstuten (Camelus dromedarius). Dtsch. tierärztl. Wschr., 97: 134-135.

Wernery, U., H.H. Schimmelpfennig, H.S.H. Seifert and J. Pohlenz, 1992. Bacillus cereus as a possible cause of haemorrhagic disease in dromedary camels (Camelus dromedarius). Proc. 1st int. Camel Conf.

Wernery, U., R. Thomas, R. Raghavan, G. Syriac and S. Joseph et al., 2008. Seroepidemiological studies for the detection of antibodies against 8 infectious diseases in dairy dromedaries of the United Arab Emirates using modern laboratory techniques - Part II. J. Camel Pract. Res., 15: 139-145. DOI: 10.1002/prca.200990001

Yousif, A.A., L.J. Braun, M.S. Saber, T. Aboelleil and C.C.L. Chase, 2004. Cytopathic genotype 2 bovine viral diarrhea virus in dromedary camels. Arab J. Biotech, 7: 123-140.

Zaghana, A., 1998. Prevalence of antibodies to bovine viral diarrhoea virus and/or border disease virus in domestic ruminants. J. Vet. Med. Series B, 45: 345351. DOI: 10.1111/j.1439-0450.1998.tb00803.x 